\title{
Innovation is creating competitive advantage: a perspective to improve the organic textile products for business growth
}

\section{REZUMAT - ABSTRACT}

\section{Inovarea este crearea unui avantaj competitiv: o perspectivă de îmbunătățire a produselor textile organice}

pentru creșterea economică

Obiectivul acestui studiu a fost de a evidenția rolul inovării în crearea avantajului competitiv și îmbunătățirea produselor textile organice pentru a dezvolta afacerile cu textile organice de pe piețele globale, pentru Pakistan. În acest studiu, inovarea este utilizată ca o strategie competitivă de către respondenții pakistanezi pentru a concura la nivel global. Factorii cei mai importanți de succes ai textilelor organice identificați în acest studiu includ calitatea, certificarea (GOTS sau Organic Exchange), serviciile pentru clienți, imaginea mărcii și alți factori de succes. Contribuția teoretică a acestui studiu include evidențierea tipurilor de inovare existente în domeniul textilelor organice și formele de inovare care predomină în această industrie.

Cuvinte-cheie: inovare, textile organice, dezvoltare economică, piață globală

Innovation is creating competitive advantage: a perspective to improve the organic textile products for business growth

This research study focused on the role of innovation for creating competitive advantage and organic textiles products improvement to develop the organic textiles business in global markets for Pakistan. In this study, innovation is used as a competitive strategy by Pakistani respondents to compete globally. The most critical success factors of organic textile identified in this research include quality, certification (GOTS or Organic Exchange), customer services, brand image, and some other success factors. The theoretical contribution of this study includes the discovery of the types of innovation which exist in organic textile and in which forms these innovations prevail in this industry

Keywords: innovation, organic textiles, business development, global market

\section{INTRODUCTION}

Innovation is the primary strength of growth, of competitiveness, of creation values, and ultimately to create maximum profitability for the firm [20].

The availability of data at the company level and new advances in the theory of economic growth highlight the significance of innovation for sustained productivity and business growth [40]. Though, our understanding on the concept of innovation, and its economic effect is still partial when it applies to develop states; most typical economists tend to suppose that fast and convenient access to modern technology to improve a firm's productivity in developing states [9]. There are little success stories of textile manufacturing products in Pakistan [40]. The value chain of textiles consisted of various industrial subsectors, and each sub-sector contributes to creating employment opportunities and value addition (Economic Survey of Pakistan, 2017-18) investigate the export competitiveness of Pakistani textile industry through GME model [32]. The mean score of GME is 382 which show that Pakistani textile industry is above average level that provide a competitive advantage over other developing nations. This study determined the importance of innovation for the survival of businesses in today's competitive world and their potential growth with a particular example of organic textile. The findings of this study would help the countries of the developing world, exclusively Pakistan, to successfully exploit organic textile opportunities for creating competitive advantage and growth available in the international markets. Currently Pakistani textile industry did not focusing the scope of organic cotton and its production. However from 2016-2017, organic cotton production globally increased approximately 10 percent, with 539,788 bales $(117,525$ metric tons) of organic cotton fiber grown by 220,478 farmers on $1,168,806$ acres $(472,999$ hectares $)$ of land in

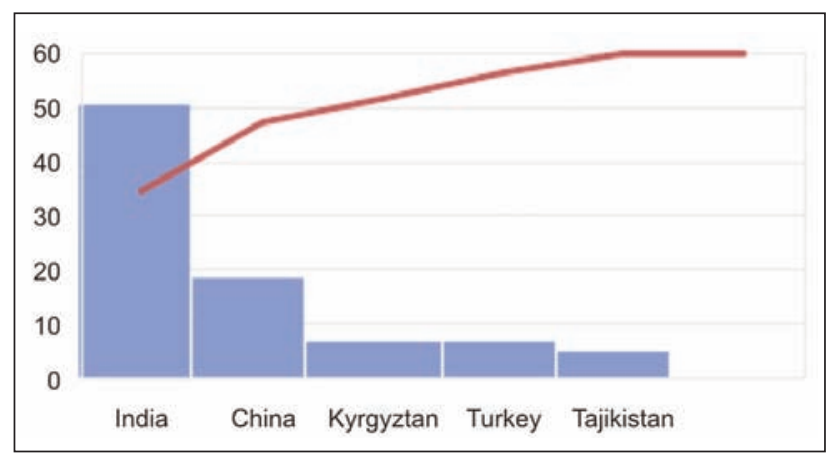

Fig. 1. Top 5 organic cotton producing countries 
18 countries. Figure 1 shows the top 5 producing countries.

\section{LITERATURE REVIEW}

Innovation process plays a significant role in the development of companies. Innovations create the competitive advantage and make the difference for companies to grow their business in domestic and foreign markets [35]. Innovation has become a critical, determinant and a key driver for the corporate success and performance [3]. However, taking more types of innovation together, increases risk levels and commitment $[5,26,11]$.

\section{Administrative innovation}

Modern research signifies that both innovation processes and leadership behaviours are affected the organization by the socio-cultural context, and it needs more research [2, 15, 39]. Administrative innovation includes rules, procedure, structures, and roles that are associated to communication, administrative processes, the introduction of new management systems, exchange between organizational members, in the organization $[10,12,25]$.

\section{Technical innovation}

Technology and technical innovations are the basis of all economies, industrial organizations and regional development [14, 16]. Technical innovations can broadly be defined as the equipment and systems of operations applied to convert raw materials or information into services or products [13] innovation can be attained through inverse engineering while the dispersal of process innovation may involve classier channels, such as industrial intelligence or expert's recruitment of competitor firms [30].

\section{Product innovation}

Product innovation is a method within organization and can be accomplished by using influences at work level [23]. Therefore, it comes under the category of voluntary product innovation [1]. Another researcher [35] focused on innovation in garment industry that provide customized products according to the need of customers. Innovation studies reveal that mostly, the emphasis is on the product and process innovation, which is considered as an instrument for adaptation and growth of organizations [31].

\section{Strategy innovation}

Strategy innovation support to improve the existing industry practices to develop new markets. With additional values, strategy innovation also works on the new emerging customers need and wants. If an organization wishes to attain the competitive advantage in micro marketing strategy, this will also be called as strategy innovation [37]. It's been thoroughly studied, and two strategy approaches have been recognized; incremental strategy innovation and radical strategy innovation [18, 38].

\section{Incremental strategy innovation}

Incremental innovation could be carried out with least alteration, commitment, and risk with sustaining the strategy. Incremental innovations are safe and infer a significant percentage of planning, and execution. Consequently, required better understanding and efficiency.

\section{Radical strategy innovation}

A radical innovation is a process or product with either unique performance characteristics or acquainted characteristics that offer significant developments in performance or cost, converting the current markets or develop new ones [5]. Radical transformation surges through market, overturning the capabilities or sometimes sweeping the incumbents away [26].

\section{Process innovation}

Many studies have revealed that process and product innovations follow several processes and do not necessarily have the same elements $[17,25,29]$. So, it is hugely recommended for any future studies to think through process innovations, and to reflect them separately [4].

\section{Market innovation}

According to [39], strategically improved marketing efforts produce a superior product performance. Firms, which can acquire new knowledge about customers and competitors successfully, apply this information to improve and develop new competence in manufacturing and marketing [40].

\section{Pull market innovation}

In this sense, a firm may develop new customers' needs just by providing information on the new product benefits or by educating customers to use it. Discovering new market opportunities and then taking benefits from them is a challenging task. By keeping a close watch on new market opportunities, they chose markets, which can be best served [1, 22].

\section{Push market innovation}

Push innovations arise from company's end, and it means that new offers are introduced. Proactive firms, whose products inherently cause their demands, develop successful push innovations [24]. In an empirical study on the relationship between innovation and the survival of industrial firms, carried out by [7] revealed that innovation helps to increase the survival likelihood of firms by $11 \%$. Considering the different dimensions of innovation, they found that process innovations play a strategic role to increase the chances of survival (up to 25\%) and create a competitive edge for firms. Whereas Product innovation effects survival only in combination with process innovation and it helps to balance the obligation of the newness of a firm [5]. 


\section{RESEARCH METHODOLOGY}

\section{Research design}

Social science methodologies are deductive approach with quantitative research methods and of the inductive approach with qualitative research methods [6]. This research study applied the random purposive sampling because the selected sample for this research consists only of those companies which are GOTS (Global Organic Textile Standard) certified in Pakistan. For this research study, primary data collected through an e-mail survey, sent to a sample of 25 Industry executives, in the form of e-mail attachment and got a response from 23 respondents.

\section{RESULTS AND DISCUSSIONS}

\section{Companies' perspective on organic textile as an innovation}

The comprehensive results are showing here on the role of innovation for the development of textile business in the form of four types of innovation (table 1). The table 1 shows that how the companies view innovation in organic textile. All the respondents who took part in this study agreed that market innovation is the most important aspect of innovation in organic textile. Then the respondents ranked product and process innovation as second and third. Almost one third of the respondents see the organic textile products from strategy innovation point of view. An in depth analysis of these four types of innovations reveals that in market innovation $73.91 \%(n=17)$ of the respondents agreed that the needs of society or a particular section of the market are behind the production or innovation of product; which would be termed as pull market innovation. These products create their own demand. One respondent said that due to more awareness about environment, people are inclining towards organic food and organic textile. From market innovation point of view only $26.09 \%(n=6)$ of the respondents see it as push market innovation - a type of innovation when an organization actively pushes the innovative product in to the market and tries to discover or develop market need related to that innovation or product.

In process innovation, only twenty respondents pointed out that they see the organic textile products in relation to process innovation. Only $82.60 \%(n=19)$ respondents say that process innovation in organic textile is improving certain processes. In this study, one respondent say "it helps to improve the systems, you cannot process organic without proper certification". In this study $04.35 \%$ i.e. only, one respondent says that their company views the process innovation in relation to organic textile as elimination of certain processes. Product innovation can be further divided into two types: one is obligatory innovation and the other is voluntary product innovation. From the results, we see that $47.83 \%(n=11)$ respondents say that they view the product innovation as a voluntary product innovation, which is the production of certain textile products on the basis of opportunities, higher profit margins and growth potential in the market. In the obligatory innovation, $39.13 \%(n=09)$ respondents say that they see the product innovation in relation to organic textile as an obligatory innovation, which is brought about by certain laws, technical requirements or on customer demand. In this study, strategy innovation is given the least importance as compared to other types. In relation to organic textile $47.83 \%(n=11)$ respondents say that they see the strategy innovation as a form of incremental strategy innovation. When an organization enters in organic textile business from traditional textile business, it would be adopting incremental strategy innovation. In this study only $26.09 \%(n=06)$ respondents see the organic textile innovation with respect to strategy as a radical strategy innovation

\section{Key variables of innovation and organic textile model}

The results of this survey provided a clear picture of how companies determine the market potential of organic textile. First, this study identified customers' demand, which has been given prime importance by the Pakistani textile companies in determining the market potential of organic textile. Second, this study identified the main factor of Innovation Research and Development. In this study, most of the respondents choose to pull market innovation approach in case of organic textile. Improving specific processes is the primary choice in process innovation.

\section{Low-value addition products producing companies}

With little variations, innovation and organic textile model can be specified for low-value added products producing companies. The survey results indicate that these companies determine the market potential based on customer demand, market survey and through R\&D. Product innovation in organic textile is viewed as voluntary product innovation, and incremental strategy innovation is the method of choice to create a drive for strategy innovation.

INNOVATION IN ORGANIC TEXTILE (ALL COMPANIES)

\begin{tabular}{|c|c|c|c|}
\hline \multicolumn{4}{|c|}{ INNOVATION IN ORGANIC TEXTILE (ALL COMPANIES) } \\
\hline Strategy Innovation & Product Innovation & Process Innovation & Market Innovation \\
\hline $73.91 \% / \mathrm{n}=17$ & $86.96 \% / \mathrm{n}=20$ & $86.96 \% / \mathrm{n}=20$ & $100 \% / \mathrm{n}=23$ \\
\hline
\end{tabular}

Note: Respondent could identify more than one $n=23$ 


\section{Medium value addition products producing companies}

In the case of process innovation, it is viewed as improving certain processes. These companies take it as voluntary product innovation to create a drive for product innovation, and incremental strategy innovation is the method of choice to bring about the strategy innovation. The most critical success factors in organic textile identified by these companies include quality, certification, customer services, and brand image. Medium value addition products producing companies are gaining benefits from organic textile innovations to increase market share, market diversification, and increased profitability.

\section{High-value addition products producing companies}

The survey results can also be translated into innovation and organic textile model for high-value added products producing companies. These companies also use customer demand, R\&D, market survey and competitor intelligence to determine market potential. Majority of companies see market innovation as pull market innovation, and only a few respondents see it as push market innovation.

\section{INNOVATION RESULTS DISCUSSION}

Like any other industry, textile industry is also becoming ever more competitive due to globalization. Companies exploit all ways to adapt to this everchanging environment and innovation is one of them. Organizations, which are seeking to enter into new markets and try to develop and maintain a competitive advantage, must use innovation to achieve these goals). This study identified four types of innovation. Among these innovation types, all the respondents agreed that they view organic textile in terms of market innovation. The other three types of innovations are mainly concerned with a company's characteristics whereas market innovation is concerned with customers and competitors, and can be further differentiated into pull market innovation and push market innovation [38]. In the survey results, companies take both perspectives. According to the results, majority of organizations see organic textile as a pull market innovation. In pull market innovation approach, firms identify demand of certain products and then they respond accordingly. Same as most of Pakistani textile organizations identify demand of organic textile products in international market and then they respond by offering organic textile products in these markets. While giving comments about pull market innovation, one respondent says, "due to more awareness about environment, people are following organic food and organic processing". Companies keep a close eye on new market opportunities and then they choose markets, which can be best served [22]. However, this research found that there are few companies, which view market innovation as a push market innovation. Companies take push market innovations by offering new products in market. Proactive firms develop successful market innovations because products of these companies create their own demands [24].

In further analysis of the results, this research divided companies into three sub-groups based on value addition in organic textile products. These subgroups include low, medium and high value addition products producing companies. Low value addition products producing companies have the same results in terms of importance for four types of innovation as the results of all the companies as a whole. In case of market innovation sub-types as pull market innovation and push market innovation, as the level of value addition products producing companies are increasing from low to high value addition, companies' response also increases towards push market innovation. Percentage level of response is increasing from low to high value addition as more companies view it as a push market innovation. Because in case of high value addition products producing companies establish their name in a market and their products, create their own demand, so these companies view organic textile market innovation as push market innovation. Another important observation from the results are that medium value addition products producing companies perceive strategy and process innovation in terms of response percentage same, as they view organic textile in terms of innovation. The level of value addition has no effect on market innovation as a major innovation type in organic textile.

This research found that most of the respondents see the organic textile as a process innovation, which is based on performing a work or an activity in a new and innovative way. Process innovation also includes issues, relating to new abilities and skills, a bigger concern for market orientation and the growth of interdepartmental communication [19]. Almost all the respondents say that the process innovation is an innovation in improving certain processes because by improving many processes help textile products to meet global organic textile standards. Third type of innovation identified is product innovation in organic textile industry. In the last two decades, there has been a considerable pressure on companies to improve quality and speed of product innovation, resulting in emergence of suitable product innovation models, which focused on the management of new product development process [8]. Generating a new product idea takes enormous creative and innovative efforts even then it is too difficult to give a practical shape to most of ideas (37). This study found that all organic textile products producing companies give almost equal importance to product and process innovation. These results are in accordance with Martinez-Ros [26], who found that product and process innovations are closely linked. In this research, most of the respondents say that they see product innovation as a voluntary product innovation in organic textile sector. The voluntary innovation in terms of textile products is that companies produce organic textile products based on opportunities available in 
this market like higher profit margins and growth potential in markets. In this research, there are companies, which view organic textile as an obligatory innovation because due to strong environmental concerns of buyers and consumers, who are purchasing and using these products based on its impact on the society and environment. Due to these pressures and obligatory requirements, companies see it as an obligatory innovation, also under umbrella of product innovation but in case of high value addition products producing companies, most of the respondents say that their companies see product innovation in organic textile as an obligatory innovation.

The fourth type of innovation, which identified in this study of organic textile, is a strategy innovation. To create a new value for both customers and organizations, the shifting of organizations business strategy is a strategy innovation [23]. The result of this research, showed that majority of companies see the strategy innovation as an incremental strategy innovation. Incremental innovations may be carried out with minimum change and less risk involvement maintaining the same strategy up to some extent. In the context of organic textile, the radical strategy innovation means that textile companies which are not producing eco-textile products; directly start production of organic textile products. One respondent in our research says about the radical strategy innovation "Gradual shift does not take you anywhere; you have to think and get it done". Due to too much experimentation, requiring greater flexibility and a higher learning curve from an organization; radical innovations are least safe. That is why only effectively developed radical innovations would ensure the long-term survival of many of today's firms [28].

\section{The innovation of organic textiles products improvement}

\section{Opportunities for Pakistan}

Pakistan has the inherent advantage of being the fourth largest cotton manufacturer in the world and textile is a vital sector of Pakistan's economy, which is contributing about more than $60 \%$ towards its growth. At present, global demand for textiles products is more than USD $\$ 300$ billion which is expected to increase about USD $\$ 800$ billion in the next 10 years. Now, Pakistan's global market share is about $3 \%$ worth about USD $\$ 10$ billion of textiles export products [21].

In collaboration with 500 smallholder farmers, C\&A Foundation and WWF Pakistan launched water testing for organic cotton cultivation trials in Balochistan in the year of 2015, and these trials yielded positive results. Now, in the region of South Asia Pakistan, India, and Thailand are producing organic cotton, which is contributing about 56 percent in the global organic cotton production while India is the leading organic cotton producer in the world (Organic cotton market report, 2017). Pakistan has a good competitive advantage and can develop good business volume in global markets.

\section{Theoretical contribution}

The theoretical contribution of this study includes the discovery of the types of innovation which exist in the organic textile and in which forms these innovations prevail in this industry. These innovations exist jointly as product innovation, process innovation, strategy innovation, and market innovation. Another theoretical contribution is the identification of the further subtypes of innovation in these innovation alternatives in the organic textile industry. This study just adds new bricks to the existing wall. The uniqueness of this study lies in the elaboration of these theoretical dimensions with respect to organic textile, which is a new and emerging industry in the textile world.

\section{Practical implications for industry}

The first practical implication is that how and by which methods, companies determine the market potential of organic textile products. Secondly, this study tried to find out the essential success factors for organic textile products for creating competitive advantage. Finally, this study considered all types of ultimate benefits; companies are gaining by developing exports business and producing organic textile products, and their subsequent effects on their overall business performance and growth.

\section{Future research directions}

The propositions developed in this study should be tested empirically. This research should be conducted in different countries with different preposition of consumers, so that it can be generalized by comparing and verifying the results. As this industry is new, so this research is exploratory in nature. More detailed research is required on each sub-sector in terms of value added products producing companies.

\section{CONCLUSION}

This study focused on four dimensions of innovation: market innovation, process innovation, product innovation and strategy innovation for creating competitive advantage and business growth. Strategy innovation is perceived mostly in the form of incremental strategy innovation. Pakistani respondents to compete in international markets use innovation as a competitive strategy. The most critical success factors of organic textile identified in this research include quality, certification (GOTS or Organic Exchange), customer services and brand image. The other success factors identified in this study by some respondents are honesty and extreme care during all the value addition processes, creating public awareness about the benefits of this environmental product and innovation, along with the development of business in global markets like Asia, Europe, and USA. 


\section{BIBLIOGRAPHY}

[1] Antonakis, J., Avolio, B. J., \& Sivasubramaniam, N. (2003). Context and leadership: An examination of the ninefactor full-range leadership theory using the Multifactor Leadership Questionnaire. In: The leadership quarterly, 14(3), pp. 261-295.

[2] Barkema, H. G., Baum, J. A., \& Mannix, E. A. (2002). Management challenges in a new time. In: Academy of Management Journal, 45(5), pp. 916-930.

[3] Becheikh, N., Landry, R., \& Amara, N. (2006). Lessons from innovation empirical studies in the manufacturing sector: A systematic review of the literature from 1993-2003. In: Technovation, 26(5-6), pp. 644-664.

[4] Benner, M. J., \& Tushman, M. L. (2003). Exploitation, exploration, and process management: The productivity dilemma revisited. In: Academy of management review, 28(2), pp. 238-256.

[5] Bitektine, A. (2008). Prospective case study design: qualitative method for deductive theory testing. In: Organizational research methods, 11(1), pp. 160-180.

[6] Cefis, E., \& Marsili, O. (2005). A matter of life and death: innovation and firm survival. In: Industrial and Corporate change, 14(6), pp. 1167-1192.

[7] Chapman, R., \& Hyland, P. (2004). Complexity and learning behaviors in product innovation. In: Technovation, 24(7), pp. 553-561.

[8] Chudnovsky, D., López, A., \& Pupato, G. (2006). Innovation and productivity in developing countries: A study of Argentine manufacturing firms' behavior (1992-2001). In: Research policy, 35(2), pp. 266-288.

[9] Daft, R. L. (1978). A dual-core model of organizational innovation. In: Academy of management journal, 21(2), pp. 193-210.

[10] Daft, R. L. (2001). Organization theory and design (7. international student edition Aufl.). In: Mason: Thomson/South-Western. Google Scholar.

[11] Damanpour, F. (1987). The adoption of technological, administrative, and ancillary innovations: Impact of organizational factors. In: Journal of management, 13(4), pp. 675-688.

[12] Damanpour, F. (1996). Organizational complexity and innovation: developing and testing multiple contingency models. In: Management science, 42(5), pp. 693-716.

[13] Dosi, G. (1988). Sources, procedures, and microeconomic effects of innovation. In: Journal of economic literature, pp. 1120-1171.

[14] Elenkov, D. S. (2002). Effects of leadership on organizational performance in Russian companies. In: Journal of Business Research, 55(6), 467-480.

[15] Fransman, M. (1999). Visions of innovation: The firm and Japan. Oxford University Press on Demand.

[16] Freel, M. S. (2003). Sectoral patterns of small firm innovation, networking and proximity. In: Research policy, 32(5), pp. 751-770.

[17] Hax, A. C. (1989). Building the firm of the future. In: MIT Sloan Management Review, 30(3), p. 75.

[18] Henard, D. H., \& Szymanski, D. M. (2001). Why some new products are more successful than others. In: Journal of marketing Research, 38(3), pp. 362-375.

[19] Ionescu, A., \& Dumitru, N. R. (2015). The role of innovation in creating the company's competitive advantage. In: Ecoforum Journal, 4(1), p. 14.

[20] Iqbal, M. S., Shaikh, F. M., Mahmood, B., \& Shafiq, K. (2010). Development of textile industrial clusters in Pakistan. In: Asian Social Science, 6(11), p. 123.

[21] Johne, A. (1996). Succeeding at product development involves more than avoiding failure. In: European Management Journal, 14(2), pp. 176-180.

[22] Johnston, R., \& Ireland, V. (1999). Picking winners: best practice in generation and selection of new business products and services. In: Technology Business Review, 1999, pp. 30-5.

[23] Kaplan, S. M. (1999). Discontinuous innovation and the growth paradox. In: Strategy \& leadership, 27(2), pp. 16-21.

[24] Kimberly, J. R. (1979). Issues in the creation of organizations: Initiation, innovation, and institutionalization. In: Academy of management Journal, 22(3), pp. 437-457.

[25] Lawless, M. W., \& Anderson, P. C. (1996). Generational technological change: Effects of innovation and local rivalry on performance. In: Academy of Management Journal, 39(5), pp. 1185-1217.

[26] Lewis, M. W., Welsh, M. A., Dehler, G. E., \& Green, S. G. (2002). Product development tensions: Exploring contrasting styles of project management. In: Academy of Management Journal, 45(3), pp. 546-564.

[27] McDermott, C. M., \& O'Connor, G. C. (2002). Managing radical innovation: an overview of emergent strategy issues. In: Journal of Product Innovation Management: an international publication of the product development \& management association, 19(6), pp. 424-438.

[28] Michie, J., \& Sheehan, M. (2003). Labour market deregulation flexibility'andinnovation. In: Cambridge journal of economics, 27(1), pp. 123-143.

[29] Ornaghi, C. (2006). Spillovers in product and process innovation: Evidence from manufacturing firms. In: International Journal of Industrial Organization, 24(2), pp. 349-380. 
[30] Pettigrew, A. M., Woodman, R. W., \& Cameron, K. S. (2001). Studying organizational change and development: Challenges for future research.

[31] Potecea, V., \& Cebuc, G. (2011). The importance of innovation in international business. In: The USV Annals of Economics and Public Administration, 10(3), pp. 157-161.

[32] Popescu, G., Olaru, S., \& Niculescu, C. (2017). Innovative design and simulation of clothing products for children with atypical changes in conformation and posture. In: DE REDACTIE, 63.

[33] Safeer, A. A., BASIT, A., ABRAR, M., ZIA-UR-REHAMAN, M. U. H. A. M. M. A. D., BAIG, S. A., \& Hashim, M. (2018). Export competitiveness analysis of Pakistan garments industry based on GEM Model. In: DE REDACTIE, 219.

[34] Sandberg B \&Sten-Olof H. (2004). Creating an international market for disruptive innovations. In: European Journal of Innovation Management, 7(1), pp. 23-32.

[35] Schneider, S. C., \& Barsoux, J. L. (2003). Managing across cultures. Pearson Education.

[36] Stevens, G. A., \& Burley, J. (1997). 3,000 raw ideas = 1 commercial success! In: Research-Technology Management, 40(3), pp. 16-27.

[37] Tornatzky, L. G., Fleischer, M., \& Chakrabarti, A. K. (1990). The processes of technological innovation. Issues in organization and management series.

[38] Vorhies, D. W., \& Morgan, N. A. (2003). A configuration theory assessment of marketing organization fit with business strategy and its relationship with marketing performance. In: Journal of marketing, 67(1).

[39] Wadho, W., \& Chaudhry, A. (2018). Innovation and firm performance in developing countries: The case of Pakistani textile and apparel manufacturers. In: Research Policy, 47(7), pp. 1283-1294.

[40] Zahra, S. A., \& George, G. (2002). Absorptive capacity. In: A review, reconceptualization, and extension. Academy of management review, 27(2), pp. 185-203.

\section{Authors:}

\section{Associate Professor ABRAR MUHAMMAD ${ }^{1}$ \\ PhD Scholar SAFEER ASIF ALI ${ }^{2}$ \\ Assistant Professor SAJJAD AHMAD BAIG ${ }^{3}$ \\ Assistant Professor BASHIR MOHSIN ${ }^{1}$ \\ FIZA AMJAD ${ }^{3}$ \\ Assistant Professor SHABBIR RIZWAN ${ }^{1}$}

${ }^{1}$ Lyallpur Business School, GC University Faisalabad, Pakistan

${ }^{2}$ School of Management, Huazhong University of Science and Technology, Wuhan, China

${ }^{3}$ Department of Management Sciences, National Textile University, Faisalabad, Pakistan

e-mail: abrarphd@gmail.com; aasafeerphd@outlook.com; sajjad.baig@hotmail.com; mohsinhust@gmail.com; rizwanshabbir@gcuf.edu.pk; fiza.amjad1@hotmail.com

\section{Corresponding author:}

\section{SHABBIR RIZWAN}

e-mail: rizwanshabbir@gcuf.edu.pk 